\title{
SHARP INEQUALITIES CONNECTED TO THE HOMOGENIZED $p$-POISSON EQUATION
}

\author{
DAG LUKKASSEN
}

Abstract. In this paper we study inequalities for the effective energy density associated with the homogenized $p$-Poisson equation. We prove that the inequalities are sharpest possible and we even find all cases of equality. Our results implies uniqueness of rank 1 laminates within the class of multi-phase structures.

Mathematics subject classification (1991): 35B27, 35J60, 73K20.

Key words and phrases: Sharp inequalities, homogenization, $p$-Poisson equation, composite structures.

\section{REFERENCES}

[1] E. F. BecKenbaCH, Convexity properties of generalized mean value functions, Ann. Math. Statist., 13 (1942) 88-90.

[2] M. P. BEnsöE, Optimization of Structural Topology, Shape, and Material, Springer-Verlag, Berlin 1995.

[3] P. S. Bullen, D. S. Mitrinović, P. M. VAsić, Means and their inequalities, D. Reidel Publishing Company Dordrecht, 1988.

[4] V. Chiado Piat, G. Dal Maso, \& A. Defranceschi, G-convergence of monotone operators, Ann. Inst. H. Poincare. Anal. Non Lineare, 7 (1990) 123-160.

[5] G. DAL MASO, An introduction to $\Gamma$-convergence, Birkhäuser, Boston, 1993.

[6] A. DEFRANCESCHI, An introduction to homogenization and G-convergence, Lecture notes, School on homogenization, ICTP, Trieste, September 6-17, (1993).

[7] G. H. Hardy, J. E. LitTlewood \& G. Pólya, Inequalities, Cambridge University Press, 1934, (1978).

[8] V. V. Jikov, S. M. KozLOV AND O. A. OleINIK, Homogenization of differential operators and integral functionals, Springer-Verlag, Berlin, 1994.

[9] D. LUKKASSEN, On estimates of the effective energy for the Poisson equation with a $p$-Laplacian, Russian Math. Surveys 51, 4, (1996), 739-740.

[10] D. LUKKASSEN, Some sharp estimates connected to the homogenized p-Laplacian equation, ZAMM-Z. angew. Math. Mech., 76 (1996) S2, 603-604.

[11] D. LUKKASSEN, Formulae and bounds connected to homogenization and optimal design of partial differential operators and integral functionals, Ph.D thesis (ISBN: 82-90487-87-8), University of Troms $\varnothing, 1996$.

[12] D. LuKKASSEN, Bounds and homogenization of integral functionals, Acta Sci. Math., 64 (1998), 301-321.

[13] D. LUKKASSEN, Homogenization of integral functionals with extreme local properties, Math. Balkanica New Series, Vol. 12, Fasc. 3-4, (1998) 339-358.

[14] D. LUKKASSEN, Means of power type and their inequalities, Math. Nachr. (to appear).

[15] D. LuKKASSEN, L. E. PERSSON AND P. WALL, On some sharp bounds for the homogenized p-Poisson equation, Applicable Anal. 58 (1995), 123-135.

[16] L. E. Persson, L. Persson, N. Svanstedt And J. Wyller, The homogenization method: An introduction, Studentlitteratur, Lund, 1993.

[17] W. Rudin, Real and Complex Analysis, Third edition, McGraw-Hill, New York, 1987. 